\title{
PEOPLE'S REPUBLIC OF
}

\section{CHINA}

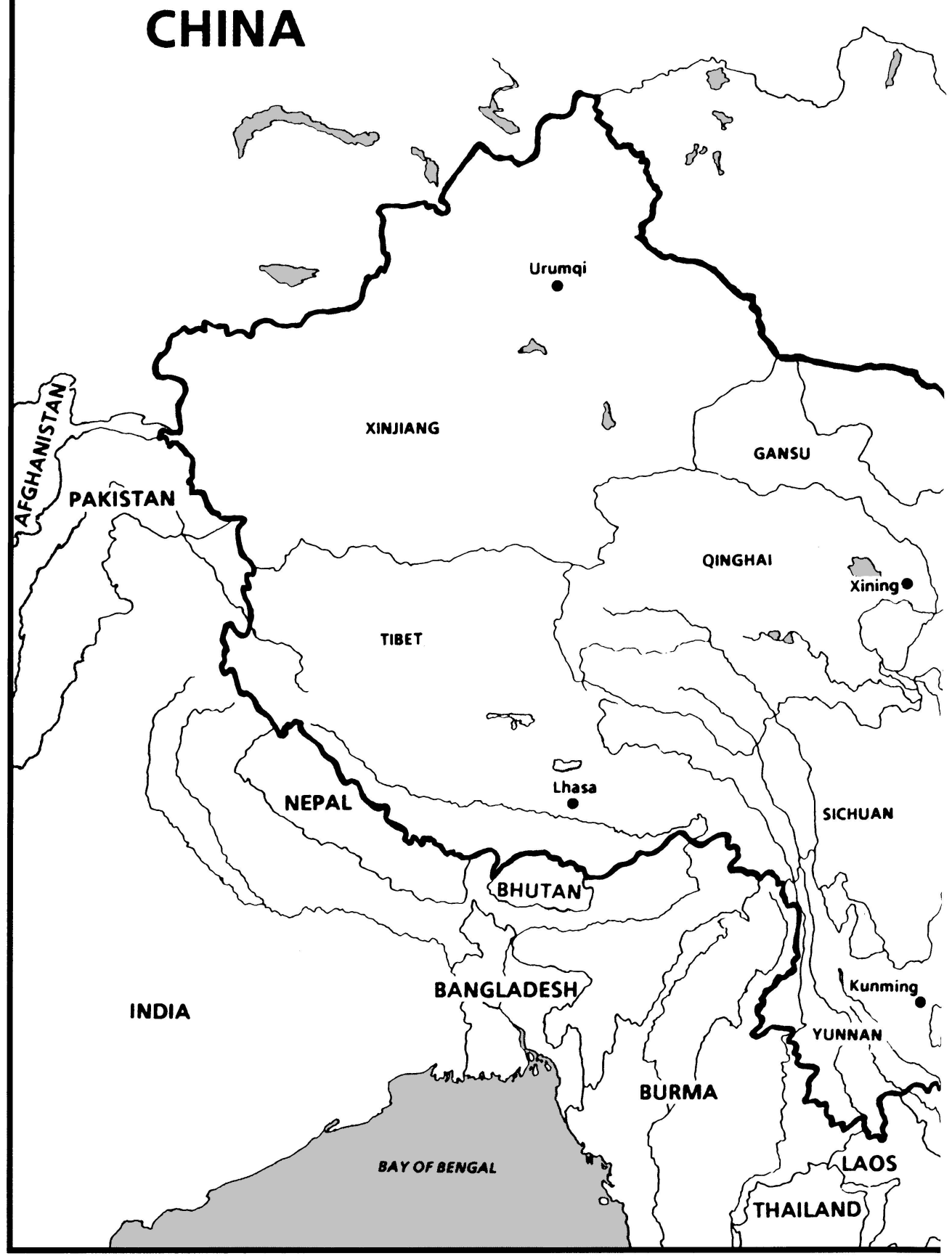




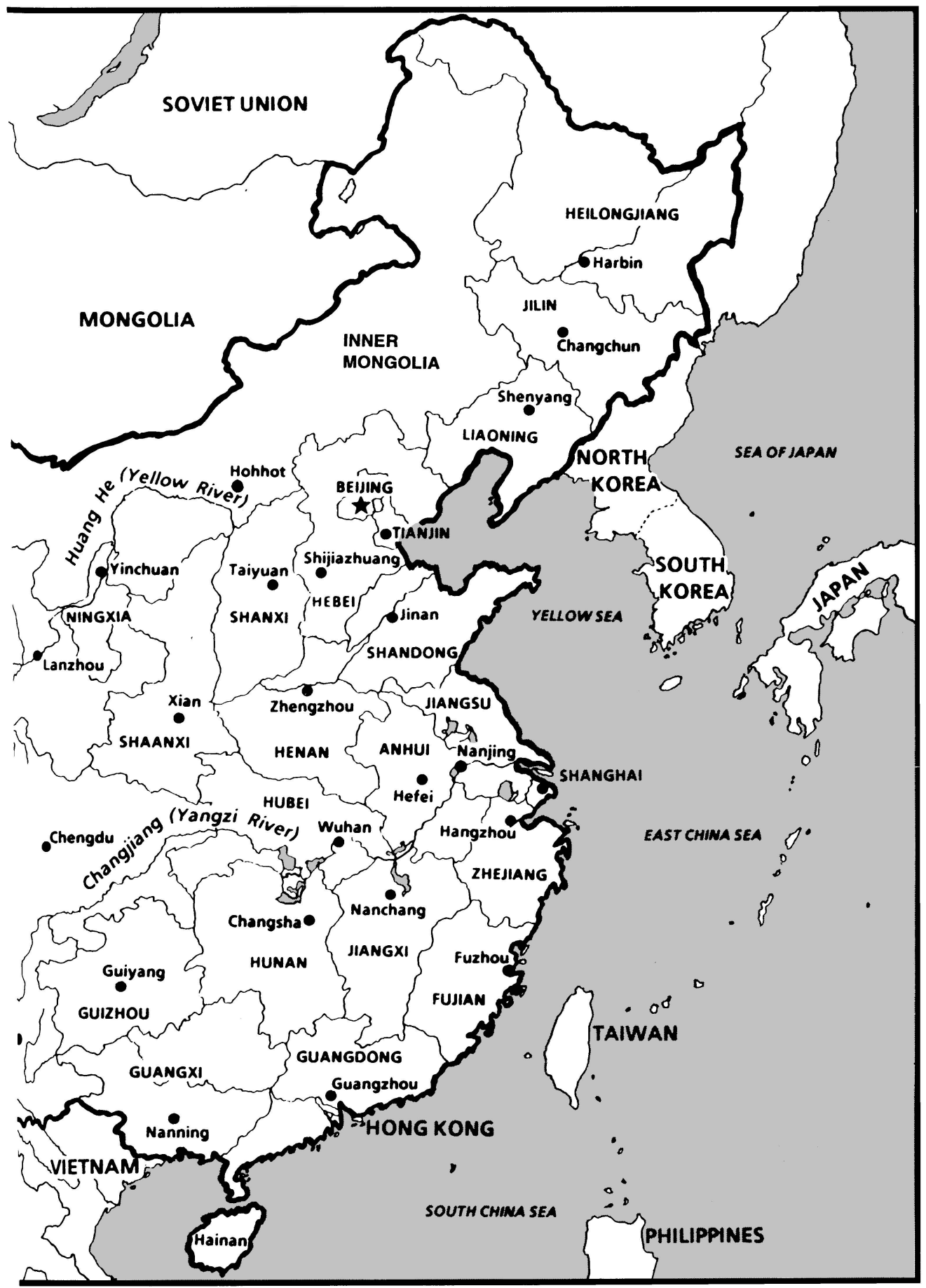


